\title{
Ce Anomaly in I-Type Granitic Soil from Kuantan, Peninsular Malaysia: Retention of Zircon in the Weathering Product
}

(Anomali Ce dalam Tanah Granit Jenis I dari Kuantan, Semenanjung Malaysia: Ketahanan Zirkon dalam Hasil Perluluhawaan)

\begin{abstract}
Azman A GHani*, MuZammil ShahJamal, NG Tham Fatt, Noer El Hidayah Ismail, Mohamad TaRmizi MOHAMAd ZULKIFley, Nur ISLAMI, QUEK LONG XIANG, AHMAD FARID ABU BAKAR, MEOR HAKIF AMIR HASSAN, JASMI HAFIZ ABDUL AZIZ \& AMIRA FAHIRA MASOR
\end{abstract}

\begin{abstract}
This paper describes the Ce anomaly observed in granitic soil from the humid, tropical area of Kuantan, Pahang, Peninsular Malaysia. Three granite rock soil profiles from Kuantan, were sampled and all samples were analysed for rare earth elements. All the profiles of the granitic soil samples show prominent positive Ce anomalies, with the Ce/Ce* ratio values $\left(\mathrm{Ce} / \mathrm{C} e^{*}=\mathrm{CeN} / \sqrt{ } \mathrm{LaN}\right.$.PrN $)$ ranging from 1.2 to 125. l. Ce $e^{4+}$ is compatible in zircon because it has also the same charge and a similar ionic radius as to $\mathrm{Zr}^{4+}\left(\mathrm{Ce}^{4+}=0.97 \AA ; \mathrm{Zr}^{4+}=0.84 \AA\right)$. The retention of zircon in the weathering product of the granitic rocks will increase the Ce content in the soil. Thus it is likely that the positive Ce anomaly in the REE profile of the Kuantan Granites may also have resulted from retention of zircon in the weathering product.
\end{abstract}

Keywords: Ce anomaly; granitic soils; mineral zircon; rare earth elements; zircon

\section{ABSTRAK}

Kertas ini menghuraikan anomali Ce yang diperhatikan di dalam tanah granit dari kawasan lembap tropika di Kuantan, Pahang, Semenanjung Malaysia. Tiga profil tanah granit dari Kuantan telah dijalankan persampelan dan kesemua sampel dianalisis untuk unsur nadir bumi. Kesemua profil tanah granit tersebut menunjukkan anomali Ce yang ketara dengan nilai nisbah Ce/Ce* $\left(\mathrm{Ce} / \mathrm{C} e^{*}=\mathrm{CeN} / \sqrt{\mathrm{LaN}} \mathrm{PrN}\right)$ berjulat antara 1.2 ke 125.1. Ce $\mathrm{e}^{4+}$ adalah sepadan di dalam zirkon kerana ia mempunyai cas dan garis pusat ionik yang sama dengan $\mathrm{Zr}^{4+}\left(\mathrm{Ce}^{4+}=0.97 \AA ; \mathrm{Zr}^{4+}=0.84 \AA\right)$. Ketahanan zirkon di dalam hasil perluluhawaan batuan granit akan menaikkan kandungan Ce di dalam tanah. Oleh itu, berkemungkinan anomali Ce positif di dalam profil REE batuan granit Kuantan disebabkan oleh ketahanan zirkon terhadap luluhawa.

Kata kunci: Anomali Ce; mineral zirkon; tanah bergranit; unsur nadir bumi; zirkon

\section{INTRODUCTION}

A relatively immobile Rare Earth Elements (lanthanide series + La) have almost an identical chemistry and is primarily found in the +3 oxidation state. During the weathering process, the elements were released from the primary mineral, leached and fractionated into the weathering product (Aubert et al. 2001; Banfield \& Eggleton 1989; Duddy 1980; Haskin 2006; Huang \& Gong 2001; Minarik et al. 1998; Nesbitt 1979; Taunton et al. 2000). All the elements in the series behave similarly during the weathering process except $\mathrm{Ce}$ and $\mathrm{Eu}$, which have +4 and +2 oxidation states, respectively. The Ce anomaly (positive and negative) has been reported and discussed in various types of geological samples including in many granitic soil profiles (Bao \& Zhao 2008; Imai et al. 2013; Leybourne et al. 2000; Mongelli 1993; Nakajima \& Terakado 2003; Ndjigui et al. 2009; Tripathi \& Rajamani 2007). Under oxidizing conditions $\mathrm{Ce}^{3+}$ can be changed to $\mathrm{Ce}^{4+}$ which is less soluble and can be fixed in secondary minerals such as clay minerals.
This paper reports an ongoing geochemical study of the basaltic and granitic soils of the tropical, humid area. The study area located at the eastern belt of Peninsular Malaysia. The area is dominated by basalt and granitic rocks surrounding the capital of Pahang state, Kuantan. The granite is an isolated pluton mainly composed of I-type fractionated hornblende biotite granite of Late Permian age (Cobbing et al. 1992; Ng et al. 2015a). Extensive land development and quarry activity had fortunately exposed a lot of the rock profiles to allow this study to be carried out. Thus, the aim of this paper is to present and discuss the possible reasons of the positive Ce anomaly in the granite soil profile.

\section{GENERAL GEOLOGY}

Peninsular Malaysia is located at the heart of the shallow water Sunda Shelf now known as Sundaland (Metcalfe 2011). Geographically the peninsular is located at the centre of Southeast Asia and is surrounded by Sumatera to the west, Thailand Peninsular to the north and Indonesia 
to the east and south. The Malay Peninsular can be divided into two tectonic terranes, the Sibumasu and the Indochina that has been divided by the Bentong Raub Suture (Metcalfe 2013, 2000). The granitic rocks from the Sibumasu and Indochina terranes are known as the Main Range Granites and the Eastern Belt Granites, respectively, were formed during the subduction and collision of the Sibumasu and Indochina blocks. The collision occurred in the Lower Permian to the Middle Triassic period, which marked the closure of the Tethys Ocean (Metcalfe 2000). The Sibumasu terrane, west of the Bentong Raub Suture, is characterized by Tin bearing, transitional I- S type granites and was emplaced around 198 to $227 \mathrm{Ma}$ (Cobbing et al. 1992; Jamil et al. 2016; Ghani 2009, 2000; Ghani et al. 2014, 2013a; Ng at al. 2015a; Searle et al. 2012). The main granite types are coarse megacrystic biotite granite and two-mica granite. To the east of the suture in Indochina block, the granites are older, and emplaced around 220$290 \mathrm{Ma}$ and are mainly I-type granites (Cobbing et al. 1992; Ghani 2009; Ghani et al. 2013b; Ng et al. 2015b). The Eastern Belt granite batholiths intrude into the gently deformed, metamorphosed Carboniferous to Triassic sediments and volcanics. The granites have been intruded by a swarm of mafic dykes (Ghani et al. 2013c).

The study area is located at the central part of the Indochina terrane and is part of the Eastern Belt granites (Figure 1). The area is underlain by two main types of igneous rocks of contrasting age that is the Permian Kuantan granite and the Pleistocene Kuantan basaltic formations. The Kuantan granite forms an isolated granitic body surrounded by Paleozoic country rocks and has been intruded by numerous Jurassic, mafic dykes (Ghani et al. 2013c; Haile et al. 1983). The younger basalt formations mainly form low-lying hills overlying the granitic rocks. Contact between these two rocks can easily be traced as the soils of the granite and basalt in this area exhibit significantly different colour and physical characteristics.

\section{WEATHERING OF KUANTAN GRANITES}

The main granite type is graded from coarse grained, primary textured equigranular to porphyritic biotite and hornblende granite (Cobbing et al. 1992) with a high $\mathrm{SiO}_{2}$ content of $>70 \% \mathrm{SiO}_{2}$. The mineralogy of the granites in decreasing abundance is $\mathrm{K}$-feldspar, quartz, plagioclase, biotite, apatite, allanite and zircon. K-feldspar occurs as large phenocrysts of up to $3 \mathrm{~cm}$ long and is characterized by perthitic texture. Quartz is mostly anhedral and generally interstitial to all the other minerals. Biotite occurs as discrete plates or ragged shreds in mafic clots and as small flakes associated with granoblastic aggregates of quartz and plagioclase. The pleochroism scheme is typically pale brown to dark brown. Zircon and apatite are the main accessory phases while hornblende occurs as individual crystals.

The humid, tropical climate with high precipitation allows the granitic rock to decompose into saprolite and lateritic soil. Thick lateritic weathering profiles have been developed over the granitic rocks in the study area. The soil profile (thickness of 2 to $10 \mathrm{~m}$ ) is characterized by boulders with size ranging from $0.5 \mathrm{~m}$ to several metres in diameter.

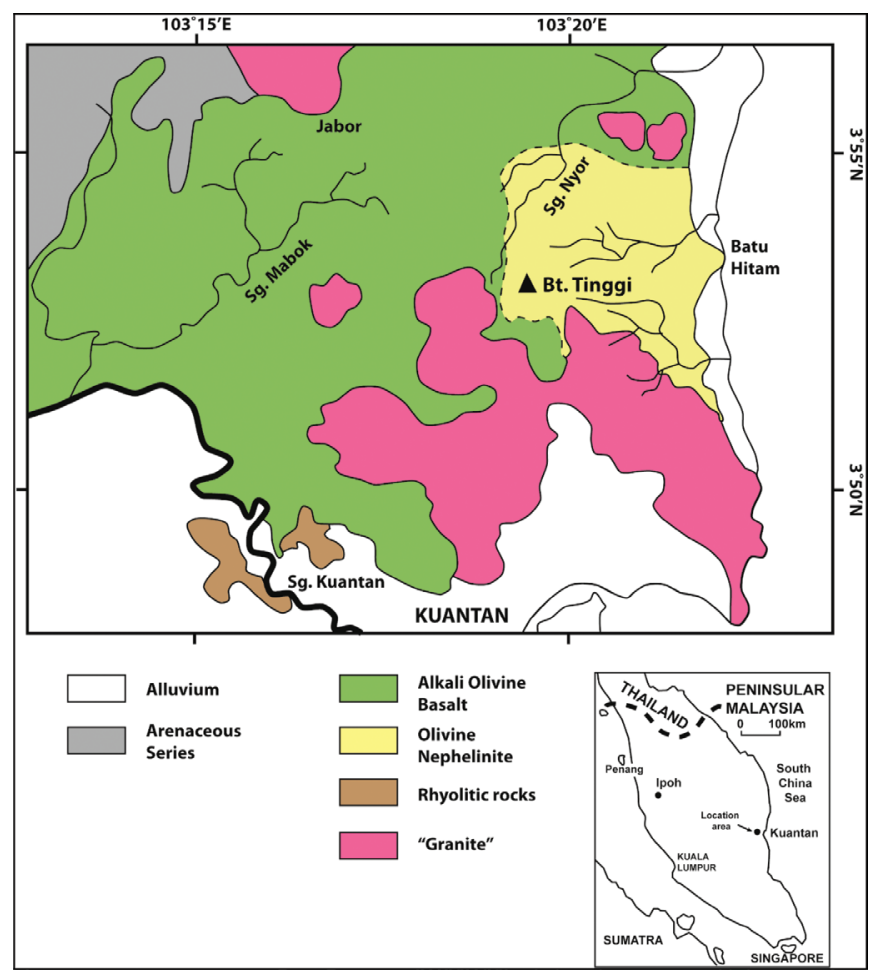

FIGURE 1. Simplified geological map of Kuantan area. Note that the granite form about $30 \%$ of the Kuantan area 


\section{GEOCHEMISTRY}

\section{METHOD}

Three representative granitic profiles along the cut slope from the study area were selected for sampling. The profiles are numbered as KG1, KG3 and KG4 and the number of samples collected from each of the profiles are 3, 4 and 4 , respectively. The description of the samples is given in Table 1. All the samples were dried and powdered to the size of $150 \mu$. After the pulverization and homogenization procedures, the samples were sent to ACME Analytical Laboratories in Vancouver, for major, trace and rare earth elements analysis. Major oxide elements and rare earth elements were analysed by using the Siemens sequential $\mathrm{X}$-Ray spectrometer and ICP MS, respectively. Calibration was done with international standards PM-S and WS-E (Govindaraju et al. 1994).

\section{RESULTS}

The results for the rare earth elements is shown in Table 2. The average total REE for the KG1, KG3, and KG4 profiles are 105, 397, and $99.5 \mathrm{ppm}$, respectively. The behaviour of REE in both rock and soil samples were investigated using a chondrite normalised diagram (Sun \& Mc Donough 1989). The diagrams for all three profiles are shown in Figures 2 to 4. For comparison, in both KG1 and KG3 profiles (Figures 2 \& 3), a fresh Kuantan granite sample profile is also given in each of the plot. All the profiles show prominent positive $\mathrm{Ce}$ anomalies, with the highest as in the sample profile $\mathrm{KG} 3$, with the $\mathrm{Ce} / \mathrm{Ce} *$ ratio values $(\mathrm{Ce} / \mathrm{Ce} *=\mathrm{CeN} / \sqrt{\mathrm{LaN}}$. $\mathrm{PrN}$ ) ranging from 1.2 to 125 . In general, all the profile are comparable to the Chondrite normalized REE pattern for zircon from magmatic zircon reported elsewhere around the world (Figure 5) (Belousova et al. 2006; Black et al. 2004; Hoskin \& Ireland 2000; Hoskin et al. 2000).

TABLE 1. Depth, colour and description of each of the samples

\begin{tabular}{|c|c|c|c|}
\hline Sample & $\begin{array}{l}\text { Depth } \\
\text { (Feet) }\end{array}$ & $\begin{array}{l}\text { Color } \\
\text { (Munsell notation) }\end{array}$ & Description \\
\hline \multicolumn{4}{|l|}{ KG1 } \\
\hline KG1-6 & $1-12$ & $\begin{array}{c}\text { Brown } \\
(10 \text { YR 5/3) }\end{array}$ & $\begin{array}{l}\text { Coarse sandy clay, Medium to fine, subangular blocky } \\
\text { grains, Compacted } \\
\text { Weathering grade } 6\end{array}$ \\
\hline KG1-5 & $12-36$ & $\begin{array}{l}\text { Pale Yellow } \\
(2.5 \mathrm{Y} 8 / 3)\end{array}$ & $\begin{array}{l}\text { Coarse sandy clay, Medium to fine, subangular blocky } \\
\text { grains, Less compacted, Weathering grade } 5\end{array}$ \\
\hline KG1-4 & $28-36$ & - & $\begin{array}{l}\text { More of than half of the rock is decomposed into soil, } \\
\text { Regolith (Fresh or discolored), Friable, No organic } \\
\text { mater. Weathering grade } 4\end{array}$ \\
\hline \multicolumn{4}{|l|}{ KG3 } \\
\hline KG3-6 & $1-5.6$ & $\begin{array}{l}\text { Light brown } \\
(7.5 \text { YR } 6 / 3)\end{array}$ & $\begin{array}{l}\text { Coarse sandy clay, Medium to fine, subangular blocky } \\
\text { grains Compacted. Weathering grade } 6\end{array}$ \\
\hline KG3-5 & $5.6-21.0$ & $\begin{array}{c}\text { Light red } \\
(2.5 \text { YR 6/6) }\end{array}$ & $\begin{array}{l}\text { Coarse sandy clay, Medium to fine, subangular blocky } \\
\text { grains, Compacted. Weathering grade } 5\end{array}$ \\
\hline KG3-4 & $21.0-29.4$ & - & $\begin{array}{l}\text { More of than half of the rock is decomposed into soil, } \\
\text { Regolith (Fresh or discolored), Mixed together with soil } \\
\text { Friable, No organic mater. Weathering grade } 4\end{array}$ \\
\hline KG3-3 & $21.0-29.4$ & - & $\begin{array}{l}\text { Less of than half of the rock is decomposed into soil, } \\
\text { Regolith (Fresh or discolored), Mixed together with soil } \\
\text { Britle. No organic mater. Weathering grade } 3\end{array}$ \\
\hline \multicolumn{4}{|l|}{ KG4 } \\
\hline KG4-6 & $1-6.5$ & $\begin{array}{l}\text { Very pale brown } \\
\quad(10 \mathrm{YR} 7 / 4)\end{array}$ & $\begin{array}{l}\text { Coarse sandy clay, Medium to fine, subangular blocky } \\
\text { grains. Compacted, Weathering grade } 6\end{array}$ \\
\hline KG4-5 & $6.5-25.4$ & $\begin{array}{l}\text { Very pale brown } \\
\quad(10 \mathrm{YR} 8 / 3)\end{array}$ & $\begin{array}{l}\text { Coarse sandy clay, Medium subangular blocky grains, } \\
\text { Compacted. No organic matter. Weathering grade } 5\end{array}$ \\
\hline KG4-4 & $19.5-25.4$ & - & $\begin{array}{l}\text { More of than half of the rock is decomposed into soil, } \\
\text { Regolith (Fresh or discolored), Mixed together with soil } \\
\text { Friable. No organic mater. Weathering grade } 4\end{array}$ \\
\hline KG4-3 & $19.5-25.4$ & - & $\begin{array}{l}\text { Less of than half of the rock is decomposed into soil, } \\
\text { Regolith (Fresh or discolored), Mixed together with soil } \\
\text { Brittle. No organic mater. Weathering grade } 3\end{array}$ \\
\hline
\end{tabular}


TABLE 2. REE content of the soil samples

\begin{tabular}{lcccccccccccccccc}
\hline Sample & Y & La & Ce & Pr & Nd & Sm & Eu & Gd & Tb & Dy & Ho & Er & Tm & Yb & Lu & $\begin{array}{c}\text { Total } \\
\text { REE }\end{array}$ \\
\hline KG1-4 & 34.4 & 2.1 & 74.6 & 0.91 & 3.6 & 1.51 & 0.14 & 3.19 & 0.78 & 5.34 & 1.07 & 3.92 & 0.61 & 3.9 & 0.65 & 102.32 \\
KG1-5 & 115.3 & 0.6 & 93.7 & 0.51 & 3.8 & 2.65 & 0.07 & 6.91 & 1.96 & 14.87 & 3.06 & 12.47 & 1.99 & 13.79 & 2.23 & 158.61 \\
KG1-6 & 32.6 & 6.9 & 19.8 & 1.97 & 6.7 & 1.72 & 0.21 & 3.01 & 0.73 & 5.29 & 1.01 & 3.92 & 0.57 & 3.72 & 0.63 & 56.18 \\
& & & & & & & & & & & & & & & & \\
KG3-3 & 38.1 & 159.6 & 377.2 & 40.62 & 138.1 & 16.66 & 2.26 & 13.09 & 1.7 & 8.45 & 1.32 & 4.5 & 0.59 & 3.87 & 0.63 & 768.59 \\
KG3-4 & 15.3 & 37 & 236 & 10.1 & 34.7 & 4.9 & 1.45 & 4.68 & 0.59 & 3.26 & 0.52 & 1.75 & 0.29 & 1.8 & 0.32 & 337.36 \\
KG3-5 & 2.9 & 1.4 & 396.8 & 0.36 & 1.3 & 0.23 & 0.12 & 1.88 & 0.08 & 0.51 & 0.1 & 0.49 & 0.09 & 0.69 & 0.12 & 404.17 \\
KG3-6 & 6.9 & 2 & 68.1 & 0.52 & 1.9 & 0.32 & 0.15 & 0.83 & 0.14 & 1.06 & 0.25 & 1.11 & 0.19 & 1.43 & 0.26 & 78.26 \\
& & & & & & & & & & & & & & & & \\
KG4-3 & 19.9 & 11.3 & 44.1 & 4.4 & 17.6 & 3.67 & 0.43 & 3.46 & 0.57 & 3.52 & 0.64 & 2.43 & 0.41 & 2.81 & 0.48 & 95.82 \\
KG4-4 & 13.5 & 4.1 & 28.9 & 1.5 & 6.4 & 1.46 & 0.27 & 1.68 & 0.33 & 2.21 & 0.44 & 1.7 & 0.31 & 2.25 & 0.38 & 51.93 \\
KG4-5 & 14.9 & 7.5 & 96 & 2.84 & 12.7 & 2.5 & 0.3 & 2.81 & 0.48 & 3.12 & 0.55 & 2.2 & 0.32 & 2.14 & 0.37 & 133.83 \\
KG4-6 & 10.4 & 3.9 & 97.6 & 1.46 & 5.4 & 1.24 & 0.13 & 1.66 & 0.29 & 1.82 & 0.36 & 1.43 & 0.22 & 1.64 & 0.29 & 117.44 \\
\hline
\end{tabular}

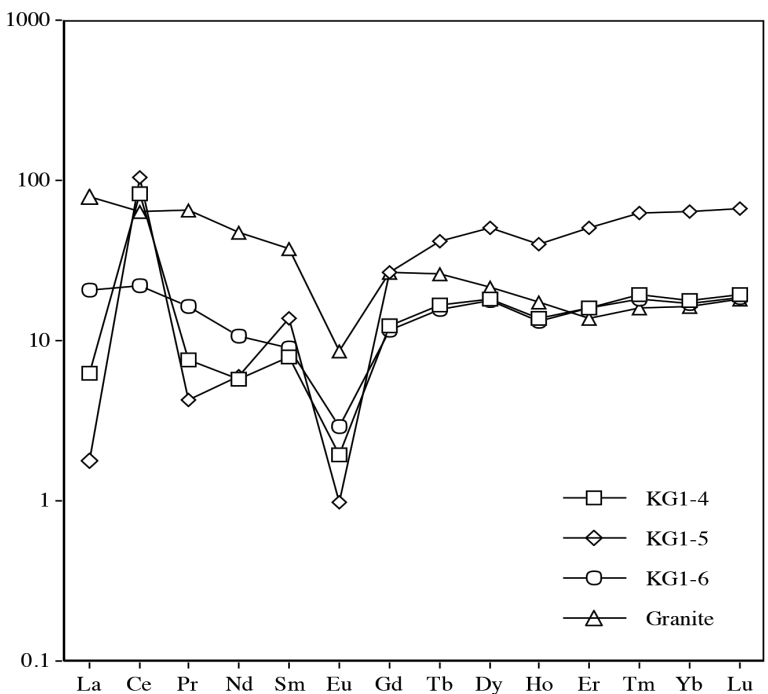

FIGURE 2. Chondrite normalized REE pattern for samples from profile KG1. Detail description of each soil sample is given in Table 1

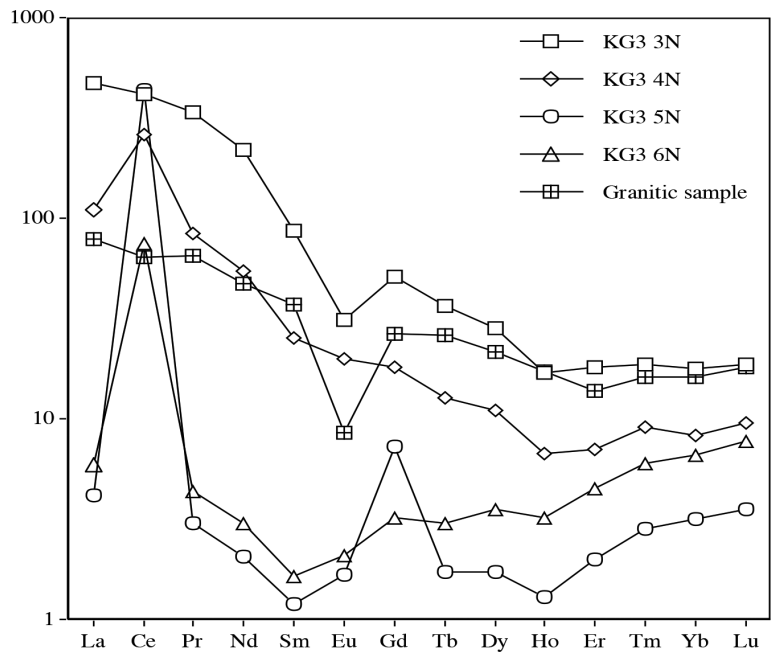

FIGURE 3. Chondrite normalized REE pattern for samples from profile KG3. Detail description of each soil sample is given in Table 1

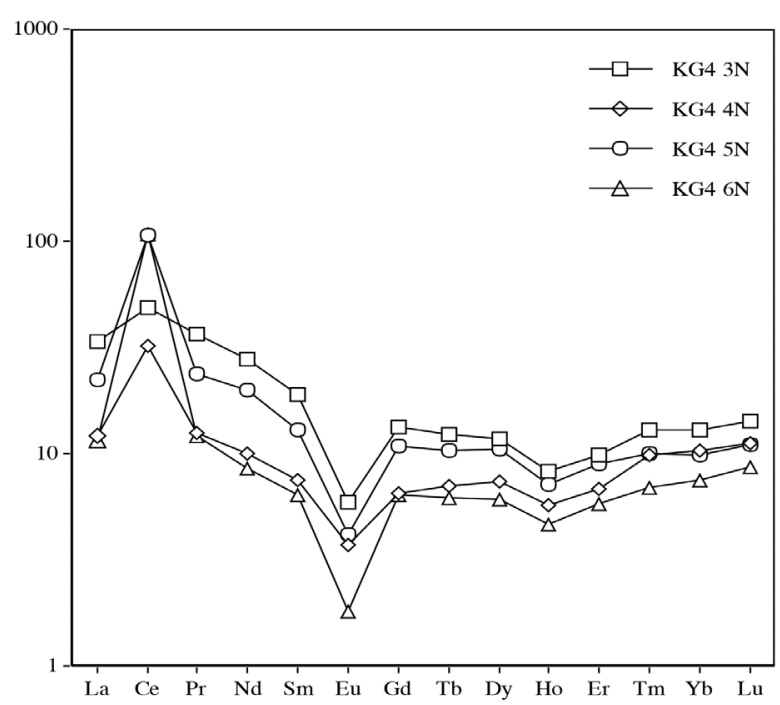

FIGURE 4. Chondrite normalized REE pattern for samples from profile KG4. Detail description of each soil sample is given in Table 1

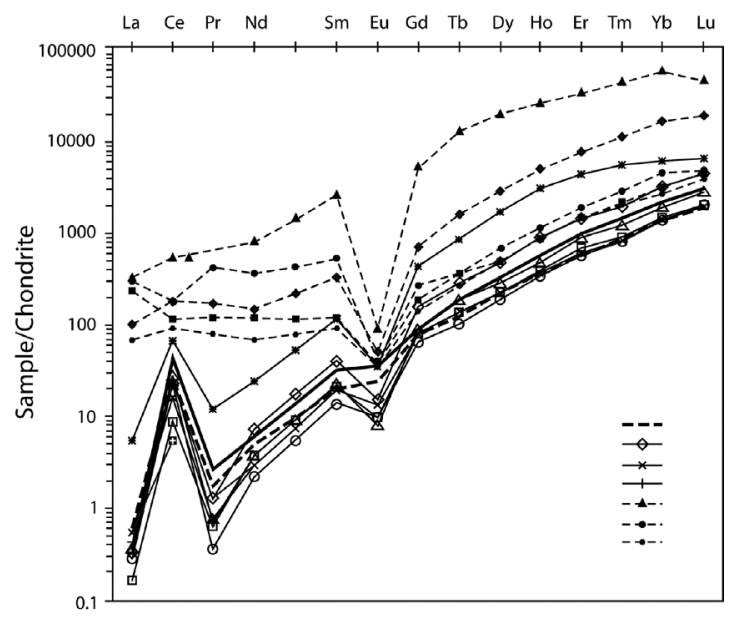

FIGURE 5. Chondrite normalized REE plot for zircon from magmatic zircon reported elsewhere around the world (Belousova et al. 2006; Black et al. 2004; Hoskin and Ireland 2000; Hoskin et al. 2000) 


\section{DISCUSSION}

Both the negative and positive $\mathrm{Ce}$ anomalies over the saprolites of various rock types have been described previously, e.g. serpentinite (Ndjigui et al. 2008); granite (Scheepers \& Rozendal 1993); dolerite (Marsh 1991) and by others (Bao \& Zhao 2008; Brown et al. 2003; Mongelli 1993). This anomaly is partly because $\mathrm{Ce}$ is the only rare earth element that is characterized by two different redox states: III and IV. This is in contrast to other rare earth element members which are only trivalent (with the notable exception of Eu2+). The $\mathrm{Ce} 3+$ can be oxidized by atmospheric oxygen $\left(\mathrm{O}_{2}\right)$ and changes to $\mathrm{Ce}^{4+}$ under alkaline condition which is less soluble and is easily fixed into secondary mineral structures such as clay minerals or, form a new phase such as cerianite. $\mathrm{Ce}^{3+}$ along with other REE will be dissolved and be removed by solution. This scenario will increase the Ce concentrations in the weathering product and may eventually lead to the high concentrations of Ce especially in the weathered residual granitic soil. High Ce concentrations in the granitic weathering product suggests that the element was rapidly precipitated during weathering and was retained in the soil.

Rare erath elements in the granitic rocks are mainly hosted in the accessory mineral such as zircon, apatite and allanite (Alderton et al. 1980; Gromet \& Silver 1983). Bao and Zhao (2008) showed that 24 to $28 \%$ of the total REE in the granitic rocks from Southeastern China, are carried by accessory minerals such as bastnaesite, parisite, gadolinite, doverite, allanite, xenotime, monazite, zircon and apatite. The behaviors of the major REE bearing accessory minerals during chemical weathering are the decisive factors affecting the accumulation of ion-exchangeable REE and differentiation of REE in the weathering profiles. Bao and Zhao (2008) divided the REE bearing accessory mineral into 3 groups following their resistance to weathering: Strongly resistant to weathering, such as xenotime and zircon; moderately resistant to weathering such as fergusonite, monazite, allanite and weakly resistant to weathering, such as bastnaesite, parisite, gadolinite-(Y) and doverite. In felsic rocks such as granitic rocks, the strong minerals are not soluble in intense weathering. An example of such a mineral is zircon, which will be preserved under extreme weathering conditions (Alfimova et al. 2011). The Kuantan granites also contain zircons as the main accessory phase. The zircon usually occurs as inclusions in biotite, accompanied with pleochroic holes. The crystals are mostly subhedral to euhedral and show long to short prismatic forms. Most zircons are transparent, colourless to pale brown and show oscillatory zoning indicative of magmatic growth. Thus, the retention of zircon in the weathering product (Alfimova et al. 2011) of the granitic rocks will increase the $\mathrm{Ce}$ content in the residual soil. $\mathrm{Ce}^{4+}$ is compatible in zircon because it has the same charge and a similar ionic radius to $\mathrm{Zr}^{4+}\left(\mathrm{Ce}^{4+}=0.97 \AA ; \mathrm{Zr}^{4+}=0.84\right.$ $\AA$ ) (Thomas et al. 2003). REE profile for magmatic zircon elsewhere around the world also show a prominent $\mathrm{Ce}$ anomaly (Figure 5). Geochemical studies of zircon from various igneous rocks (Belousova et al. 2010) also showed that most of the zircons have a positive $\mathrm{Ce}$ anomaly. The studies showed that when the $\mathrm{Ce}^{3+}$ in zircon oxidised to $\mathrm{Ce}^{4+}$, it behaved more like $\mathrm{Zr}$.

\section{CONCLUSION}

All the profiles of the granitic soil samples show prominent positive $\mathrm{Ce}$ anomalies, with the $\mathrm{Ce} / \mathrm{Ce}$ * ratio values $(\mathrm{Ce} /$ $\mathrm{Ce}^{*}=\mathrm{CeN} / \sqrt{\mathrm{LaN}} . \mathrm{PrN}$ ) ranging from 1.2 to $125.1 . \mathrm{Ce}^{4+}$ is compatible in zircon because $\mathrm{Ce}^{4+}$ has also the same charge and a similar ionic radius as to $\mathrm{Zr}^{4+}\left(\mathrm{Ce}^{4+}=0.97 \AA\right.$; $\mathrm{Zr}^{4+}=0.84 \AA$ ). The retention of zircon in the weathering product of the granitic rocks will increase the Ce content in the soil. Thus it is likely that the positive Ce anomaly in the REE profile of the Kuantan Granites may also have resulted from retention of zircon in the weathering product.

\section{ACKNOWLEDGEMENTS}

The work was partly sponsored by the University of Malaya (UMRG Grant No. RG263/13AFR and the UM/MOHE High Impact Research Grant UM.C/625/HIR/MOHE/SC/23).

\section{REFERENCES}

Alderton, D.H.M., Pearce, J.A. \& Potts, P.J. 1980. Rare earth element mobility during granite alteration: Evidence from southwest England. Earth Planet. Sci. Lett. 49: 149-165.

Alfimova, N.A., Matrenichev, V.A., Zinger, T.F. \& Skublov, S.G. 2011. Geochemistry of zircon from the Proterozoic weathering profile of granitoids in Norhern Karelia. Doklady Earth Sciences 438(1): 632-635.

Aubert, D., Stille, P. \& Probst, A. 2001. REE fractionation during granite weathering and removal by waters and suspended loads: $\mathrm{Sr}$ and $\mathrm{Nd}$ isotopic evidence. Geochimica et Cosmochimica Acta 65(3): 387-406.

Banfield, J.F. \& Eggleton, R.A. 1989. Apatite replacement and rare earth mobilization, fractionation and fixation during weathering. Clays and Clay Minerals 37: 113-127.

Bao, Z. \& Zhao, Z. 2008. Geochemistry of mineralization with exchangeable REY in the weathering crusts of granitic rocks in South China. Ore Geology Reviews 33: 519-535.

Belousova, E.A., Griffin, W.L. \& O'Reilly, S.Y. 2006. Zircon crystal morphology, trace element signatures and $\mathrm{Hf}$ isotope composition as a tool for petrogenetic modeling: Examples from eastern Australian granitoids. Journal of Petrology 47: 329-353.

Belousova, E.A., Griffin, W.L., O’Reilly, S.Y. \& Fisher, N.I. 2002. Igneous zircon: Trace element composition as an indicator of source rock type. Contribution of Mineralogy and Petrology 143: 602-622.

Black, L.P., Kamo, S.L., Allen, C.M., Davis, D.W., Aleinikoff, J.N., Valley, J.W., Mundil, R., Campbell, I.H., Korsch, R.J., Williams, I.S. \& Foudoulis, C. 2004. Improved 206 Pb/238U microprobe geochronology by monitoring of a trace-elementrelated matrix effect: SHRIMP, ID-TIMS, ELA-ICP-MS and oxygen isotope documentation for a series of zircon standards. Chemical Geology 205: 115-140.

Brown, D.J., Helmke, P.A. \& Clayton, M.K. 2003. Robust geochemical indices for redox and weathering on a granitic 
laterite landscape in Central Uganda. Geochimica et Cosmochimica Acta 67(15): 2711-2723.

Cobbing, E.J., Pitfield, P.E.J., Darbyshire, D.P.F. \& Mallick, D.I.J. 1992. The granites of the South-East Asian tin belt. Overseas Memoir 10, British Geological Survey.

Duddy, L.R. 1980. Redistribution and fractionation of rare-earth and other elements in a weathering profile. Chemical Geology 30: 363-381.

Ghani, A.A. 2009. Plutonism. In Geology of Peninsular Malaysia, edited by Hutchison, C.S. \& Tan, D.N.K. University of Malaya and Geol. Soc. Malaysia. pp. 211-232.

Ghani, A.A. 2000. The Western Belt granite of Peninsular Malaysia: Some emergent problems on granite classification and its implication. Geosciences Journal 4(4): 283-293.

Ghani, A.A., Hazad, F.I., Azmiah, J., Quek, L.X., Wan Ismail, W.N.A., Chung, C.S., Lai, Y.M., Roselee, M.H., Nur Islami, Nyein, K.K., Amir Hassan, M.F., Abu Bakar, M.F. \& Umor, R. 2014. Permian Ultrafelsic A-type granite from besar islands group, Johor, Peninsular Malaysia. Journal Earth Science System 123(8): 1857-1878.

Ghani, A.A., Searle, M., Robb, L. \& Chung, S.L. 2013 a. Transitional I-S type characteristics in the Main Range Granite, Peninsular Malaysia. Journal of Asian Earth Sciences 76: 225-240.

Ghani, A.A., Yusoff, I., Amir Hassan, M.H. \& Ramli, R. 2013b. Geochemical study of volcanic and associated granitic rocks from Endau Rompin, Johor, Peninsular Malaysia. Journal of Earth System Science 122(1): 65-78.

Ghani, A.A., Lo, C.H. \& Chung, S.L. 2013c. Basaltic dykes of the eastern Belt of Peninsular Malaysia: The effects of the difference in crustal thickness of Sibumasu and Indochina. Journal Asian Earth Sciences 77: 127-139.

Govindaraju, K., Potts, P.J., Webb, P.C. \& Waston, J.S. 1994. Report on Whin Sill dolerite WS-S from England and Pitscurie microgabbro PM-S from Scotland: Assessment by one hundred and four international laboratories. Geostandards Newsletter 18(2): 211-300.

Gromet, L.P. \& Silver, L.T. 1983. Rare earth element distributions among accessory minerals in a granodiorite and their petrogenetic implications. Geochimica et Cosmochimica Acta 47: 925-939.

Haile, N.S., Beckinsale, R.D., Chakraborty, K.R., Hanif, H. \& Hardjono, T. 1983. Paleomagnetism, geochronology and petrology of the dolerite dykes and basaltic lavas from Kuantan, West Malaysia. Geological Society of Malaysia Bulletin 16: 71-85.

Haskin, D. 2006. Chemical and mineralogical weathering indices as applied to a granite saprolite in South Africa. IAEG2006 Paper number 465. pp. 1-14.

Hoskin, P.W.O. \& Ireland, T.R. 2000. Rare earth element chemistry of zircon and its use as a provenance indicator. Geology 28: 627-630.

Hoskin, P.W.O., Kinny, P.D., Wyborn, D. \& Chappell, B.W. 2000. Identifying accessory mineral saturation during differentiation in granitoid magmas: An integrated approach. Journal of Petrology 41: 1365-1396.

Huang, C.M. \& Gong, Z.T. 2001. Geochemical implication of rare earth elements in process of soil development. J. Rare Earth 19: 57-62.

Imai, A., Yonezu, K., Sanematsu, K., Ikuno, T., Ishida, S., Watanabe, K., Pisutha-Arnond, V., Nakapadungrat, S. \& Boosayasak, J. 2013. Rare earth elements in hydrothermally altered granitic rocks in the Ranong and Takua Pa Tin-Field, Southern Thailand. Resource Geology 63(1): 84-98.
Jamil, A., Ghani, A.A., Zaw, K., Osman, S. \& Quek, L.X. 2016. Origin and tectonic implications of the $\sim 200 \mathrm{Ma}$, collisionrelated Jerai pluton of the Western Granite Belt, Peninsular Malaysia. Journal of Asian Earth Sciences 127: 32-46.

Leybourne, M.I., Goodfellow, W.D., Boyle, D.R. \& Hall, G.M. 2000. Rapid development of negative $\mathrm{Ce}$ anomalies in surface waters and contrasting REE patterns in groundwaters associated with $\mathrm{Zn}-\mathrm{Pb}$ massive sulphide deposits. Applied Geochemistry 15(6): 695-723.

Marsh, J.S. 1991. REE fractionation and Ce anomalies in weathered Karoo Dolerite. Chemical Geology 90: 189-194.

Metcalfe, I. 2000. The Bentung-Raub suture zone. Journal of Asian Earth Sciences 18: 691-712.

Metcalfe, I. 2011. Tectonic framework and Phanerozoic evolution of Sundaland. Gondwana Research 19: 3-21.

Metcalfe, I. 2013. Tectonic evolution of Malay Peninsular. Journal of Asian Earth Sciences 76: 195-213.

Minarı, L., Zigova, A., Bendl, J., Skrivan, P. \& St'astny, M. 1998. The behaviour of rare-earth elements and $\mathrm{Y}$ during the rock weathering and soil formation in the Ricany granite massif, Central Bohemia. The Science of the Total Environment 215: 101-111.

Mongelli, G. 1993. REE and other trace elements in a granitic weathering profile from 'Serre', Southern Italy. Chemical Geology 103: 17-25.

Nakajima, T. \& Terakado, Y. 2003. Rare earth elements in stream waters from the Rokko granite area, Japan: Effect of weathering degree of watershed rocks. Geochemical Journal 37: 181-198.

Ndjigui, P.D., Bilong, P. \& Bitom, D. 2009. Negative cerium anomalies in the saprolite zone of serpentinite lateritic profiles in the Lomié ultramafic complex, South-East Cameroon. Journal of African Earth Sciences 53: 59-69.

Ndjigui, P.D., Bilong, P., Bitom, D. \& Dia, A. 2008. Mobilization and distribution of major and trace elements in two weathering profiles developed on serpentinites in the Lomié ultramafic complex, South-East Cameroon. Journal of African Earth Sciences 50: 305-328.

Nesbitt, H.W. 1979. Mobility and fractionation of rare earth elements during weathering of a granodiorite. Nature 279: 206-210.

Ng, S.W.P., Chung, S.L., Robb, L.J., Searle, M.P., Ghani, A.A., Whitehouse, M.J., Oliver, G.J.H., Sone, M., Gardiner, N.J. \& Roselee, M.H. 2015a. Petrogenesis of Malaysian granitoids in the Southeast Asian tin belt: Part 1. Geochemical and Sr-Nd isotopic characteristics. Geol. Soc America Bull. doi: 10.1130/B31213.1.

Ng, S.W.P., Whitehouse, M.J., Searle, M.P., Robb, L.J., Ghani, A.A., Chung, S.L., Oliver, G.J.H., Sone, M., Gardiner, N.J. \& Roselee, M.H. 2015b. Petrogenesis of Malaysian granitoids in the Southeast Asian tin belt: Part 2. U Pb zircon geochronology and tectonic model. Geol. Soc America Bull. doi: 10.1130/B31214.1.

Scheepers, R. \& Rozendaal, A. 1993. Redistribution and fractionation of $\mathrm{U}, \mathrm{Th}$ and rare-earth elements during weathering of subalkaline granites in SW Cape Province, South Africa. J. Afr. Earth Sci. 17: 41-50.

Searle, M.P., Whitehouse, M.J., Robb, L.J., Ghani, A.A., Hutchison, C.S., Sone, M., Ng, S.W.P., Roselee, M.H., Chung, S.L. \& Oliver, G.J.H. 2012. Tectonic evolution of Sibumasu-Indochina terrane collision zone in Thailand and Malaysia - constraints from new U-Pb zircon chronology of SE Asian tin granitoids. Journal of the Geological Society London 169: 489-500. 
Sun, S.S. \& McDonough, W.F. 1989. Chemical and isotopic systematics of oceanic basalts: Implications for mantle composition and processes. Geological Society of London Special Publications 42: 313-345.

Taunton, A.E., Welch, S.A., Jillian, F. \& Banfield, J.F. 2000. Geomicrobiological controls on light rare earth element, $\mathrm{Y}$ and $\mathrm{Ba}$ distributions during granite weathering and soil formation. Journal of Alloys and Compounds 303-304: 30-36.

Thomas, J.B., Bodnar, R.J., Shimizu, N. \& Chesnar, C.A. 2003. Melt inclusions in zircon. Review in Mineralogy and Geochemistry 53(1): 63-87.

Azman A Ghani*, Ng Tham Fatt, Noer El Hidayah Ismail, Mohamad Tarmizi Mohamad Zulkifley, Quek Long Xiang, Ahmad Farid Abu Bakar, Meor Hakif Amir Hassan, Jasmi Hafiz Abdul Aziz \& Amira Fahira Masor Department of Geology Faculty of Sciences, University of Malaya 50603 Kuala Lumpur, Federal Territory Malaysia
Muzammil Shahjamal

Reservoir Geoscience Department

Level 11, Tower 2, Petronal Twin Tower KLCC

50088 Kuala Lumpur, Federal Territory

Malaysia

Nur Islami

Physics Education, PMIPA

Universitas Riau, Pekanbaru, 28293

Indonesia

*Corresponding author; email: azmangeo@um.edu.my

Received: 16 May 2018

Accepted: 14 September 2018 